\title{
Power (Lessness) of the State in Globalisation Era: Empirical Proposals on Determination of Domestic Paddy Price in Thailand
}

\author{
Kittisak Jermsittiparsert ${ }^{1,4}$, Thanaporn Sriyakul ${ }^{2,4}$ \& Sudarat Rodboonsong ${ }^{3}$ \\ 1 Department of Political Science, College of Government and Public Governance, Rangsit University, \\ Pathumthani, Thailand \\ 2 Department of Management, Faculty of Business Administration, Mahanakorn University of Technology, \\ Bangkok, Thailand \\ ${ }^{3}$ Department of Social Sciences, Faculty of Humanities and Social Sciences, Uttaradit Rajabhat University, \\ Uttaradit, Thailand \\ ${ }^{4}$ The Political Science Association of Kasetsart University, Thailand \\ Correspondence: Kittisak Jermsittiparsert, Department of Political Science, College of Government and Public \\ Governance, Rangsit University, Pathumthani, Thailand; The Political Science Association of Kasetsart \\ University, Thailand. Tel: 66-8-6622-2495. E-mail: kittisak.j@rsu.ac.th
}

Received: August 5, 2013 Accepted: September 28, 2013 Online Published: November 29, 2013

doi:10.5539/ass.v9n17p209 URL: http://dx.doi.org/10.5539/ass.v9n17p209

\begin{abstract}
In the context of globalisation, states are insinuated as little homes in the global village. Although arguments on change of powers in the current situation are widely made qualitatively, quantitative analysis by empirical information is still minimal. This study, therefore, chose an advanced quantitative methodology, using time series data on domestic paddy price, cost of domestic rice production, rice world market price, and the government-determined price according to its policy, in multiple regression analysis.

The research findings show that, as the cost of domestic rice production does not influence domestic paddy price, at statistical significance of .05 , the domestic paddy price is in fact more affected by the rice world market price, which represents the power of globalisation, than by the price determined by the government, which represents the power of the state, at statistical significance of .05, for approximately 4.78 times, indicating that state power in this context is no longer in the position to bargain with the power of globalisation. Hence, policy recommendations continue to be regarded with the adjustments of economic management, in which the current Thai government still chooses to utilise great amount of its budget to intercept the market price of rice.
\end{abstract}

Keywords: power (lessness) of the state, globalization era, domestic paddy price

\section{Introduction}

"It is widely asserted that we live in an era in which the greater part of social life is determined by global processes, in which national cultures, national economies and national borders are dissolving. Central to the perception is the notion of a rapid and recent process of economic globalization."

"A truly global economy is claimed to have emerged or to be in the process of emerging, in which distinct national economies and, therefore, domestic strategies of national economic management are increasingly irrelevant."

"The world economy has internationalized in its basic dynamics, it is dominated by uncontrollable market forces, and it has as its principal economic actors and major agents of change truly national transnational corporations the owe allegiance to no nation-state and locate wherever on the globe market advantage dictates" (Hirst \& Thompson, 1999, p. 1)

\section{1 "State" and "Globalisation"}

It has been considered for a very long time that "state" is the core of political science studies, or at least since Aristotle, the Greek philosopher who was dubbed "The Father of Political Science", wrote a text titled "Politics", and proclaimed with this masterpiece that "it is only in a state that human can achieve the ultimate happiness" (Aristotle, 2001, p. 1127). Until late $20^{\text {th }}$ century, important political scientists such as Samuel Huntington (1997, 
p. 33), including Kenneth Waltz (1979), each has expressed that state was the sole player that had some significance in international affairs and systems, and John Stoessinger (1990, p. 6) reiterated that, in our generation, there would be no human that could avoid the system of nation-state, unless one took a refuge to the freezing cold north or south poles or to other planets.

Under the historical conditions, this type of political community began its evolution from the Tribal State, Oriental Empire, Greek City-States, Roman Empire, through to the Feudal State, all of which had no definite territory (Wongsurawat, 2000, p. 22-23), until the kings of various states mutually agreed to the treaty of westphalia in 1648, after an extensive 30 years at war caused by religious differences, and thus established the principle of territorial sovereignty as well as the compliance to the terms of legal boundaries of states and not to intervene in the affairs of other states for any reason whatsoever. (Opello \& Rosow, 2004, p. 79)

In brief, the newly emerged modern state shall therefore constitute of at least four fundamental constituents (Wanthana, 2009, p. 97-98):

1) A definite territory; hence this makes the modern state often being called "territorial state".

2) A permanent population; generally, a modern state would require its population to share common similarities or characteristics, referred to as a nationality, and thus make such modern state being recognised as a "nation state."

3) A government to maintain communal harmony among its population and manage relationships with external persons or entities; such government includes the party appointed via political process, or the administration, along with its mechanism which is the permanent employees of both central and local officials.

4) Sovereignty; with an authority governing a definite territory freely, the international law and the tradition of international diplomatic affairs would recognise such to its own sovereignty, possessing the qualities of absolute, comprehensiveness, permanence and indivisibility.

Michael Mann (1986, p. 7-10; cited in Linklater, 2001, p. 620) has made two remarks on the occurred change. Firstly, a modern state is able to foster internal intensive power deep in the society, and secondly, a modern state is also able to establish extensive power beyond the boundary of the state, as Immanuel Wallerstein (2004, p. 42-43) has stated that sovereignty, a product of the modern times, is a claim of authority not only internally but externally, that is, vis-a-vis other states.

As a result, such keyword like "imperialism" has been defined to denote the acquisition of sovereignty of a state by means of conquest, expansion of economic and political domination, as well as dominion over the others (Spiegel, 1995, p. 185). Having decided to act as such, the european superpowers established a wide connection for the very first time in the global system. Empires were expanding overseas and across continents until there was almost no land that Europe Imperialism could not reach, whether it was America, Australia, Africa, or even Asia (Opello \& Rosow, 2004, p. 167). Ultimately, this process has developed itself into such phenomenon known as "globalisation" in the present days (Robins, 1999, p. 344; cited in Lawson, 2007, p. 120).

\section{2 "Power (?) of the State" in "Globalisation Era"}

Although states were once the driven force of the globalisation course in the past (Linklater, 2001, p. 621), but as soon as the gears of the such phenomenon can work at full capacity, globalisation would become a machine that brings about a revolution which states, as its initiators, cannot control, go against, or resist any further (Held, McGrew, Goldblatt \& Perraton, 1999, p. 1). On the contrary, states would fall into a defensive position, being threatened, or even losing their power, particularly the ability to control and regulate the economic aspects (Lawson, 2007, p. 123), and under such circumstance, it would hardly be possible for any state to formulate their economic policies without regarding the ongoing international trends (United Nations, 1990, p. 1).

Alvin Toffler (1989, p. 263-267) is a person who has made an interesting remark on the power status of the states under the current situation that any state that deems itself as an absolute sovereign is in fact a mere entity too small to play any role on the global stage. The close economic relationships between nations in the present would render each government of those nations incapable of implementing its economic policies freely. Such power once held by nations is being limited sharply and governments would face with problems beyond national level. Every country is currently facing sovereignty instability; such state power will be gradually lost as the world system progresses to supersede.

\section{3 "Thai State" and "Globalisation"}

As for Thai state, the historical milestone which many scholars considered as the beginning of the modern era and the integration to the trend of reducing a state to a small house in the global village was when King Mongkut 
(Rama IV) signed the Bowring Treaty with Sir John Bowring, the Governor of Hong Kong in the name of Queen Victoria, on the $18^{\text {th }}$ of April, 1855.

Regarding the main objectives of this treaty, Atcharaporn Kamutpissamai (2007, p. 371) has expressed an opinion that they are the intention of western superpowers to use Thailand as a market for goods, a place to mine resources, and a destination for investments of capitalistic nations.

Apart from regarding this treaty as unequal and disadvantaged to Thailand (Maneepurk, 2007, p. (3-7)), the outcomes of the treaty also forced Thailand to accept the principle of colonial international division of labour, which gave Thailand the duty to produce specific goods to meet the demands of the world market, and changed the structure of commodity trade, especially export goods, consequently reducing the categories of goods to only a few, such as rice, teakwood, tin, and so on (Kamutpissamai, 2007, p. 372-373), among which rice was the most important (Ruangsin, 1990, p. 251). The ratio of export to the amount producible per year increased from 17 percent to 47 percent (Rural Reconstruction and Friends Alumni, 2002), accounted for 70 percent of all export goods (Kamutpissamai, 2007, p. 373), and the production pattern has changed its emphasis from domestic consumption to international trade (Rural Reconstruction and Friends Alumni, 2002).

\section{4 "Domestic Paddy Price Determination" and "Power (?) of Thai State"}

Provided that rice has been one of the significant economic crops for a long time (Patmasiriwat \& Punyasavatsut, 199 , p. 2), or at least from the moment when the growth of rice productivity after Bowring Treaty signing occurred, both in the dimension of cultivation areas which rose from 5.8 million rai in 1850 to 20.07 million rai in 1930 and 67.6 million rai in 2006, and that of the rice output which rose from 1.15 million ton in 1895 , through to 2.94 million ton in 1930, and more than 10 million ton in 2004 (Maneepurk, 2007, p. (3-13); Department of Internal Trade of Thailand, 2010b), thus positioning Thailand as one of the top producers and especially the world's biggest exporter of rice. The market price of rice has therefore become a subject of interest to the economists in this country since.

A research of Direk Patmasiriwat and Chaiyuth Punyasavatsut (1990) titled "Rational Expectations: A Case Study of Rice Price" and a research of the School of Economics, University of the Thai Chamber of Commerce, titled "A Project to Create a Monitoring and Warning System for Agricultural Products: Rice", including a work of Prayong Netayarak (2007) on "Agricultural Economics", have pointed out that the rice market price depends on a number of factors at least three; the production cost, the demand and supply of the world market, and the government policies.

Considering the facts about the domestic rice price in Thailand, which tend to be based on the paddy ( $5 \%$ grade) price due to its popularity among farmers and its highest yield potential, along with its status of being a general standard merchandise in the market (Chaiyawonnagal, 2010), has revealed that many governments from different eras had made decisions in the same manner to use the power of the state to interfere with the price consecutively in various forms, such as charging export fees (rice premium), export taxes, rice reserves, setting export quotas (Siamwalla \& Setboonsarng, 1988; cited in Patmasiriwat \& Punyasavatsut, 1990) and rice pledging scheme (Netayarak, 2007, p. 271-273) until it shifts into income guarantee scheme for farmers nowadays, which has a significant objective to raise the price level of paddy (Netayarak, 2007, p. 271) rather than leaving the price to change freely through market mechanism.

Anyhow, supposing such factor of government policy implemented to interfere with the price is a representation of state power, the factor of rice demand and supply in the world market could likewise be regarded as a representation of the power of globalisation, conflicting against each other through the domestic paddy price.

As a result of a preliminary investigation, it has yet to be found that there is a study or research aiming to investigate the influences of the three factors, especially the government policies and the demand and supply of the world market, regarding which is related to which, as well as which has the greater impact on the domestic paddy price, to indicate the relative of power status between states and globalisation in an empirical approach.

In consequence to the lack of any substantial study or research to support, any rising problems would thus be for the government to address, as it is the decision-maker in selecting the appropriate policy to implement, which eventually become a heavy burden to overall national budget without any clear indication that all the money spent has been worthwhile, especially under the circumstance of being a mere small house in this global village.

\subsection{Objective of the Research}

This research is conducted in order to fulfil at least two objectives on both research and the highest levels respectively as follows: 
The first objective is to analyse the relationship between the domestic paddy price ( $5 \%$ grade), the cost of domestic rice production, the rice world market price, and the government-determined price, as it would led to a recognition of whether the determination including the alteration of the domestic paddy price is under the influence of the other three factors or not, along with the magnitude of such impact if it were.

Another objective is to examine the power of the state in globalisation era whether there were any remained or how much there were comparing to the power of globalisation via earlier empirical data on the relationship between each factor, as well as the influence of the factor of domestic rice production cost, and especially the factor of rice world market price, as it is a representation of the power of globalisation, together with the factor of government-determined price, as it is a representation of the power of the state, to the domestic paddy price.

\section{Research Methodology}

\subsection{Data and Variables}

The researchers selected a time series data gathered from numerous related organisations and authorities, verified by the secretariat of the National Rice Policy Committee, Department of Internal Trade, Ministry of Commerce, covering the period of 67 months from January of 2005 to July of 2010, on the following variables:

1) The domestic paddy price (5\% grade) (PRICE), as it is the most cultivated rice with the highest yield potential and a general standard merchandise in the market, from the Bureau of Agricultural Products Trade Promotion (2010), herein defined as the dependent variable.

2) The domestic rice production cost (COST), in place of the cost of production factor, from the Agriculture Information Centre (2010), herein defined as an independent variable.

3) The rice world market price (WORLD), in place of the factor of rice demand and supply in the world market, from the Board of Trade of Thailand and the Department of Freign Trade (2010), herein defined as an independent variable.

4) The government-determined price (GOVPRICE), in place of the government policy factor, from the Department of Internal Trade (2010a; 2010c), herein defined as an independent variable.

\subsection{Data Analysis}

The data was analysed by means of advanced statistics, multiple regression analysis, using computer application software.

\section{Research Results}

The researchers have divided the results of this research into two sections, where the first presents the result of the analysis of descriptive data obtained from time series data of each variable in respective order; the domestic paddy price, the cost of domestic rice production, the rice world market price, and the government-determined price.

The second section is an analysis on the relationships between the variables via multiple regression analysis, presented in respective order: the relationship between the domestic paddy price and the rice world market price and the cost of domestic rice production; the relationship between the domestic paddy price and the government-determined price; the relationship between the domestic paddy price and the rice world market price and the government-determined price; lastly, the relationship between the government-determined price and the rice world market price and the cost of domestic rice production.

\subsection{The Domestic Paddy Price}

At the beginning, from January 2005 to January 2008, the domestic paddy price had been fluctuating between 5,803 THB/MT and 6,863 THB/MT until it started to ascend to 8,066 THB/MT in February 2008, reaching its peak at 13,445 THB/MT two months afterwards, and began to decline gradually to 7,925 THB/MT in July 2010.

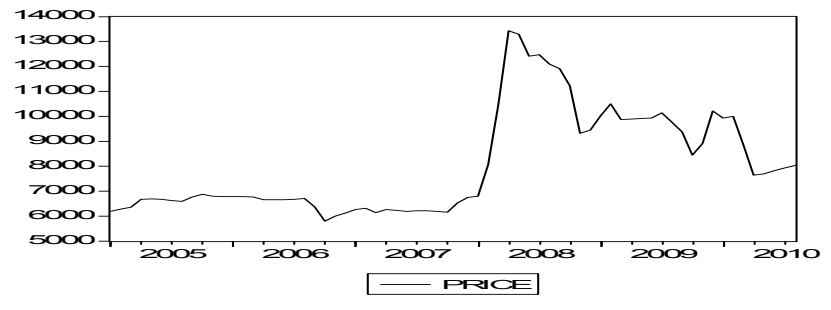

Figure 1. Domestic paddy price 


\subsection{The Cost of Domestic Rice Production}

The cost of domestic rice production had a tendency to increase continuously from 2005 , as the cost at 5,602 THB/MT went up to $6,905 \mathrm{THB} / \mathrm{MT}$ in the following year and onwards to reach a peak of $8,859 \mathrm{THB} / \mathrm{MT}$ in 2009 , before falling slightly to 8,715 THB/MT in 2010 .

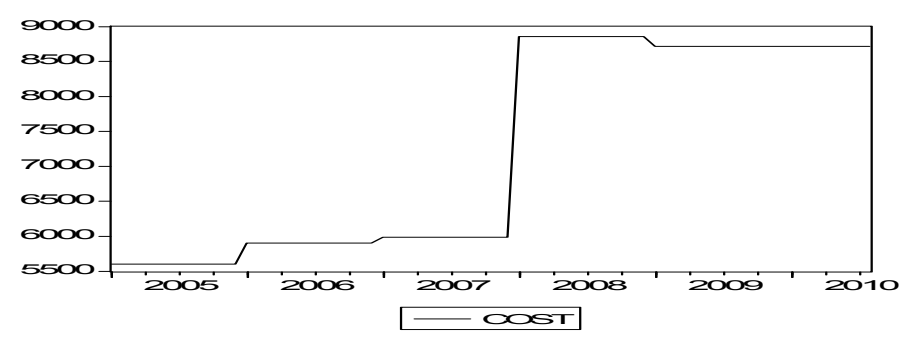

Figure 2. Cost of domestic rice production

\subsection{The Rice World Market Price}

The rice world market price at first, from January 2005 to December 2007, had been fluctuating within a narrow range of $279 \mathrm{USD} / \mathrm{MT}$ to $362 \mathrm{USD} / \mathrm{MT}$, prior to its increase in January 2008 to $481 \mathrm{USD} / \mathrm{MT}$ onwards to reach a peak in the following four months of 973 USD/MT, and then began to fall down to 438 USD/MT in July 2010.

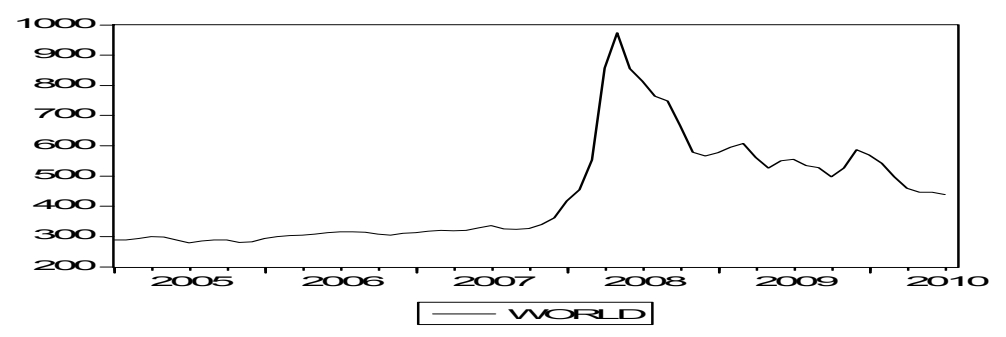

Figure 3. Rice world market price

\subsection{The Government-Determined Price}

The government-determined price was divided into two phases according to the schemes implemented by the government to interfere with the price, that is, in the first phase of rice pledging scheme, from January 2005 to December 2009, the government had determined the price of rice pledging at 6,500 THB/MT in 2005, 7,000 THB/MT in 2006, 6,400 THB/MT in 2007, 6,600 THB/MT in 2008, and 11,800 THB/MT in 2009, followed by the second phase implementing income guarantee scheme since January 2010 onwards with a guaranteed price at $10,000 \mathrm{THB} / \mathrm{MT}$.

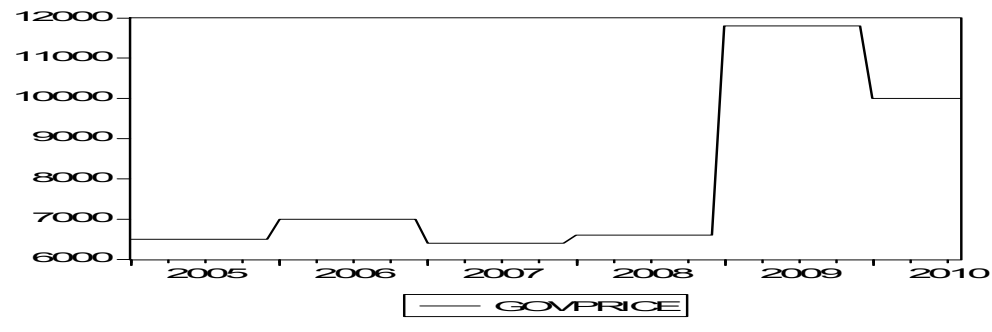

Figure 4. Government-determined price

Upon analysing the time series data above with naked eyes prior to subjecting it to a correlation test by means of advance statistics, the multiple regression analysis, it demonstrates that the four variables all share similar data trends and movement directions. 


\subsection{Relationship between Domestic Paddy Price and Rice World Market Price and Cost of Domestic Rice Production}

The initial stage is to validate whether or not the domestic paddy price has any relationship to the factor of production cost, inherent to the producer party, herein being the variable of the cost of domestic rice production; and the rice demand and supply in the world market, inherent to the consumer party, herein being the variable of the rice world market price.

Table 1 indicates that although the domestic paddy price does not have a relationship with cost of domestic rice production at statistical significance of .05 , it has a positive correlation to the rice world market price at the statistical significance level of .01. Furthermore, the rice world market price can explain the domestic paddy price at as much as $94.84 \%$.

Basically, it can be concluded that the domestic paddy price is unrelated to the cost of domestic rice production, or the cost of production factor, but closely related to the variable of rice world market price, or the factor of rice demand and supply in the world market, that is.

Table 1. Multiple regression analysis on domestic paddy price and rice world market price and domestic rice production cost

\begin{tabular}{llll}
\hline Variable & B & T & Sig \\
\hline Constant & 2607.814 & 5.004482 & 0.0000 \\
World & 11.53577 & 11.31586 & 0.0000 \\
Cost & 0.055593 & 0.472681 & 0.6380 \\
Adj $\mathrm{R}^{2}$ & 0.948405 & $\mathrm{~F}$ & 607.6016 \\
Sig f & 0.0000 & & \\
\hline
\end{tabular}

\subsection{Relationship between Domestic Paddy Price and Government-Determined Price}

Next step is to validate whether or not the domestic paddy price has any relationship to the government-determined price, as the government tries to be a player who intervenes with market mechanism, apart from producer and consumer parties mentioned earlier, herein being the variable of government-determined price.

Table 2 indicates that the government-determined price has a positive correlation with the domestic paddy price at statistical significance of .01 , yet it is a variable that can explain the domestic paddy price at only $15.37 \%$

Hence, the analysis in this step leaves only two variables that are positively correlated to the domestic paddy price, namely the variable of the rice world market price, or the factor of rice demand and supply in the world market, which apart from being inherent to the consumer party, it is also a representation of the power of globalisation; and the variable of government-determined price, or the factor of price determined by government policy, which other than being a gear in market mechanism intervention, it is also a representation of the power of the state.

Table 2. Multiple regression analysis on domestic paddy price and government-determined price

\begin{tabular}{llll}
\hline Variable & B & T & Sig \\
\hline Constant & 5012.686 & 3.381446 & 0.0012 \\
GovPrice & 0.384888 & 2.814105 & 0.0064 \\
$\mathrm{R}^{2}$ & 0.153723 & $\mathrm{~F}$ & 11.98866 \\
Sig $\mathrm{f}$ & 0.000944 & & \\
\hline
\end{tabular}

\subsection{Relationship between Domestic Paddy Price and Rice World Market Price and Government-Determined Price}

The analysis in this step is to validate whether the rice world market price or the government-determined price 
has any relationship as well as which has a greater influence to the flux of domestic paddy price, at what extent if so, which also implies the comparison of effect between the power of the state and the power of globalisation to the determination of such domestic paddy price.

Table 3 indicates that, when bringing the variable of world market price into multiple regression analysis together with the variable of government-determined price, the positive correlation of the latter to the domestic paddy price has increased to .0403 at .05 statistical significance level from .0064 at significance of .01 , while the variable of rice world market price remains positively correlated to the domestic paddy price at statistical significance of .01 . The two variables can explain the domestic paddy price at $95.22 \%$, respectively.

Moreover, Table 3 also indicates that, for each 1 USD that changes in the rice world market price, the domestic paddy price would relatively alter at $11.66 \mathrm{THB}$ in the same direction, whereas it would alter accords to each 1 THB that changes in the variable of government-determined price at a mere 0.07 THB in the same direction. If equating the currency of USD to THB at the exchange rate of 1 USD to 30 THB and compare, it will reveal that the influence of the variable of rice world market price to the domestic paddy price is approximately 4.78 times greater than that of the variable of government-determined price.

With such validation that the influence of the variable of rice world market price to the domestic paddy price is greater than that of the variable of government-determined price, which also implies the greater power globalisation holds over the government in modern days, the questions arise in the heart-and-mind of the people would normally concern on which basis that the government used to determine the policy price and whether the extent of the attention that the government gives to the variable of rice world market price, a great influence on the domestic paddy price, the product of choice the government interferes with, as well as to the variable of the cost of domestic rice production, or the cost of production to the farmers, is truly adequate.

Table 3. Multiple regression analysis on domestic paddy price and rice world market price and government-determined price

\begin{tabular}{llll}
\hline Variable & B & T & Sig \\
\hline Constant & 2422.185 & 7.109551 & 0.0000 \\
World & 11.65876 & 27.36304 & 0.0000 \\
GovPrice & 0.067235 & 2.092827 & 0.0403 \\
Adj R & 0.952152 & F & 607.6805 \\
Sig f & 0.0000 & & \\
\hline
\end{tabular}

\subsection{Relationship between Government-Determined Price and Rice World Market Price and Cost of Domestic Rice Production}

This last step is to convert the variable of government-determined price to a dependent variable and define the variables of rice world market price and the cost of domestic rice production as independent to validate whether the latter two have a correlation to, as well as an influence on, the dependent variable or not, in which direction and at what magnitude, if any.

Table 4 indicates, despite the fact that the variable of domestic rice production cost has a positive correlation with the rice world market price and the government-determined price at statistically significance level of .01 , the variable of rice world market price is negatively correlated to the government-determined price at statistical significance of .01, which the two can explain the government-controlled price at $50.64 \%$.

Accordingly, for every 1 THB that changes in the variable of domestic rice production cost, the government-determined price would relatively change by 1.70 THB in the same direction; whereas every 1 USD that changes in the variable of rice world market price would alter the government-determined price in the opposite direction by $8.23 \mathrm{THB}$, thus if equating the currency of USD to THB and compare, it will show that ratio of change in the variable of rice world market price to the government-determined price is 1 THB to 0.27 THB in the opposite direction. 
Table 4. Multiple regression analysis on government-determined price and rice world market price and cost of domestic rice production

\begin{tabular}{llll}
\hline Variable & B & T & Sig \\
\hline Constant & -678.3329 & -0.372568 & 0.7107 \\
World & -8.232870 & -2.664335 & 0.0098 \\
Cost & 1.695677 & 3.773268 & 0.0004 \\
Adj R & 0.506364 & F & 34.85094 \\
Sig f & 0.000000 & & \\
\hline
\end{tabular}

\section{Conclusion and Recommendation}

\subsection{Conclusion}

The descriptive analysis of the time series data in overall has revealed that domestic paddy price, cost of domestic rice production, rice world market price, and government-determined price all share similar data trends and positively correlated, that is, the first period, from January 2005 to December 2007 or January 2008, there are fluctuations within a narrow range in the data before they ascend to reach the peaks around April or May of 2008 and then decline afterwards.

The analysis of the relationships between the domestic paddy price and the cost of domestic rice production, the rice world market price and the government-determined price has revealed that the cost of domestic rice production is unrelated at statistical significance of .05 , while the rice world market price has a positive correlation at statistical significance of .01 and so does the government-determined price at .05 . Additionally, the rice world market price has an influence to the domestic paddy price 4.78 times greater than that of the government-determined price.

Apart from that, the analysis of the relationship between the government-determined price and the cost of domestic rice production and the rice world market price has revealed that the domestic rice production cost is positively correlated at statistical significance of .01 , whereas the rice world market price is negatively correlated at statistical significance of 01 .

In conclusion, the result indicates that the current circumstance, where the factor of production cost has no effect on the determination of paddy domestic price, and the factor of government policies that aim to interfere with such price have proven ineffective compared to the demand and supply of rice in the world market, is an evidence of the deteriorating power status of the state in this globalisation era, which is virtually nonexistence in practice. Though, it does not seem to have been realised by Thai government, which appears to believe throwing a vast amount of national budget at the problems is effective, even though many states in the world have known for a fact that it is not.

\subsection{Recommendation}

This analysis of empirical data on the determination of domestic paddy price would prove to be a useful tool to remind the government and any other people that they should be cognizant of "the powerlessness of the state in globalisation era" as this is the time when government has ceased to be the sole player in politics and must manage its affair to survive. Such populist policies implemented without thoroughly considering external factors, which have grown more important over time, would not only be like an act of dumping national budget to fill an ocean, which is practically unfulfillable, but also indirectly harm the people of the nation and constrain its own competitiveness development potentials under realistic environment in the process.

The policy recommendation from the researchers hereinto would therefore regard to adjusting the pattern of economic management under the context of globalisation, which the government should not and, in fact, could not effectively continue to intervene in rice price. In the short run, any possibilities to improve technology, production and processing, as well as subsidising (if required), should be considered promptly and timely. As for the long run, to produce other type of commodity may have to be considered as a means to solve this chronic problem should the short term measures provided for have proven to be inadequate.

\section{References}

Aristotle. (2001). POLITICA. Translated by B. Jowett. In R. McKeon (Ed.), The Basic Works of Aristotle (pp. 1113-1316). New York: The Modern Library.

Board of Trade of Thailand \& Department of Foreign Trade. (2010). Rice Export Prices F.O.B. Bangkok.

Bureau of Agricultural Products Trade Promotion. (2010). Average Prices of Major Paddy and Second Paddy (at $15 \%$ Moisture Content), Lat Yao and Pitsanulok Central Markets].

Centre for Agriculture Information. (2010). Costs of Rice Production. 
Chaiyawonnagal, J. (2010, September). Deputy Director-General of the Department of Internal Trade, Ministry of Commerce. Interview, 18.

Department of Internal Trade of Thailand. (2010a). Income Guarantee Scheme for Rice Farmers, Crop Years 2009/2010 (Round 1 and Round 2).

Department of Internal Trade of Thailand. (2010b). Monthly Summary on Rice Export Quantities.

Department of Internal Trade of Thailand. (2010c). Rice Pledging Prices, Periods, and Quantities: Year 2001/2002 - Present.

Held, D., McGrew, A., Goldblatt, D. \& Perraton, J. (1999). Global Transformations: Politics, Economics, Culture. Cambridge: Polity.

Hirst, P., \& Thompson, G. (1999). Globalization in Question: The International Economy and the Possibilities of Governance. Cambridge: Polity.

Huntington, S. (1997). The Clash of Civilizations and the Remaking of World Order. New York: Touchstone.

Kamutpissamai, A. (2007). Economic, Social and Politics in Thailand. In Course Production Committee of Thai Social and Political History. Teaching Material of Thai Social and Political History Course: Modules, (1-7), 349-406. Nonthaburi: Sukhothai Thammathirat Open University.

Lawson, S. (2007). A Short Introduction to International Relations. (Reprinted). Cambridge: Polity.

Linklater, A. (2001). Globalization and the Transformation of Political Community. In J. Baylis \& S. Smith, The Globalization of World Politics: An Introduction to International Relations (2nd ed.) (pp. 617-633). New York: Oxford University Press.

Maneepurk, C. (2007). Development of Economic and Political System from Bowring Treaty to before the Siamese Revolution of 1932". In Course Review Committee of Thai Political Economy. Teaching Material of Thai Political Economy Course: Modules, (1-7), (pp. (3-1)-(3-48)). Nonthaburi: Sukhothai Thammathirat Open University.

Netayarak, P. (2007). Agricultural Economics. Bangkok: Thammasat University.

Opello, J. W., \& Rosow, S. (2004). The Nation-State and Global Order: A Historical Introduction to Contemporary Politics (2nd ed.). Colorado: Lynne Rienner.

Patmasiriwat, D., \& Punyasavatsut, C. (1990). Rational Expectations: A Case Study of Rice Price. Bangkok: Economics Association of Thailand.

Ruangsin, C. (1990). Economic and Commercial History of Thailand from Ancient Time to 1856 A. D. In P. Hantrakool (Ed.). Bangkok: Ton-or.

Rural Reconstruction and Friends Alumni. (2002). Impacts of Trade Liberalization under the Agreement on Agriculture (AoA) of the World Trade Organization: A Case Study of Rice. Asia-Pacific Research Network Journal, 7.

School of Economics, University of Thai Chamber of Commerce. (2006). A Project to Create a Monitoring and Warning System for Agricultural Products: Rice. Bangkok: School of Economics, University of Thai Chamber of Commerce.

Spiegel, S. (1995). World Politics in a New Era. Fort Worth: Harcourt Brace.

Stoessinger, J. (1990). The Might of Nations: World Politics in Our Time (9th ed.). New York: McGraw-Hill.

Toffler, A. (1989). The Third Wave. Translated by S. Terarbnij (Ed.). Bangkok: Yin-Yang.

United Nations. (1990). The World Economy: A Global Challenge. Department of Public Information, United Nations.

Waltz, K. (1979). Theory of International Politics. Massachusetts: Addison-Wesley.

Wanthana, S. (2009). Globalisation Process and Its Social Impacts. Faculty of Social Science, Kasetsart University (lecture notes distributed in Analysis of Social Sciences, Doctor of Philosophy Program in Social Science, Kasetsart University, $12^{\text {th }}$ November 2009).

Wongchaisuwan, T. (1994). Globalisation 2000. Bangkok: Pim Dee.

Wongsurawat, K. (2000). Principles of Political Science and Politics in the $21^{\text {st }}$ Century. Nakhon Pathom: National Agricultural Extension and Training Center.

\section{Copyrights}

Copyright for this article is retained by the author(s), with first publication rights granted to the journal.

This is an open-access article distributed under the terms and conditions of the Creative Commons Attribution license (http://creativecommons.org/licenses/by/3.0/). 